\title{
Evaporation Retardation by Monomolecular Layers: An Experimental Study at the Aji Reservoir (India)
}

\author{
Kishor Panjabi ${ }^{1}$, Ramesh Rudra', Pradeep Goel ${ }^{2}$ \\ ${ }^{1}$ School of Engineering, University of Guelph, Guelph, Canada \\ ${ }^{2}$ Environmental Monitoring and Reporting Branch, Ontario Ministry of the Environment, Toronto, Canada \\ Email: kpanjabi@uoguelph.ca
}

Received 7 December 2015; accepted 26 April 2016; published 29 April 2016

Copyright (C) 2016 by authors and Scientific Research Publishing Inc.

This work is licensed under the Creative Commons Attribution International License (CC BY). http://creativecommons.org/licenses/by/4.0/

(c) (i) Open Access

\begin{abstract}
It is an established fact that huge quantities of water are lost from lakes, reservoirs and soils by evaporation. This assumes greater significance in arid and semi-arid regions around the globe when a general scarcity of water is compounded by high evaporation loss from the open water surfaces of lakes and reservoirs. The use of surface covering by a monomolecular film to reduce evaporation loss from large open water surfaces offers the greatest promise among all currently available techniques. This is the only system that retains the water surface in a state that does not interfere with other uses of the body of water such as boating, navigation recreation, fish, and wildlife propagation. Various experiments and field trials worldwide have proven conclusively that the fatty alcohols and their emulsions effectively retard water evaporation and result in saving to the tune of about $20 \%$ to $50 \%$. An experiment was carried out at the Aji Reservoir (India) using a mixture of Cetyl and Stearyl alcohol that confirmed $19.26 \%$ saving in evaporation loss. During this six-month trial, about 0.18 mcum of water was saved which otherwise might have evaporated.
\end{abstract}

Keywords

Evaporation, Water Evaporation Retardant, Monomolecular Layer, Cetyl Alcohol, Stearyl Alcohol

\section{Introduction}

The rapid increase in world population and per capita consumption of water due to rising standards of living and other levels of activity have greatly intensified the demand for water all over the world. Evaporation plays a

How to cite this paper: Panjabi, K., Rudra, R. and Goel, P. (2016) Evaporation Retardation by Monomolecular Layers: An Experimental Study at the Aji Reservoir (India). Open Journal of Civil Engineering, 6, 346-357. 
major role in the hydrologic cycle, and about $50 \%$ to $75 \%$ of total rainfall lost to the atmosphere [1]-[3]. This assumes greater significance in arid and semi-arid regions. The situation becomes grave, especially during droughts, when a general scarcity of water is compounded by high evaporation losses from the open water surfaces of lakes and reservoirs [4]. The National Water Commission (Australia) Waterlines Report Series No. 80, June 2012, documents annual evaporation losses in Australia as potentially exceeding $40 \%$ of total water storage.

Evaporation is a type of vaporization of water that occurs on the surface of liquid. Water evaporation is the process of escaping water molecules from the water surface into the atmosphere. The major factors that influence this process are temperature, humidity, the wind and exposed surface area [5]-[7]. As the process of evaporation is invisible, these losses in water are often not recognized. Evaporation is greatest during the driest seasons which are also the peak periods of water use [8] [9]. Management of water by reducing the evaporation rates will optimize the amount of water that may support the ever-growing domestic, agricultural and industrial demands. Hence, potentially all of the evaporation controlling methods can be of great economic significance [10]-[13].

Among the various techniques for reducing evaporation loss, mechanical devices, such as shed clothes and floating covers, have demonstrated the effectiveness for small storages, but they are not feasible for large areas of water such as reservoirs [14]-[17]. For large storage, the use of mono-molecular layers has the potential to be an attractive and cost-effective solution to reduce evaporation [18]-[20]. Mono-molecular layers are films that have the thickness of one molecule and form at the phase boundary of the air/water interface.

Many organic compounds, such as surfactants, detergents, bile salts or Phospholipids are amphiphilic, which combine a hydrophilic and a hydrophobic moiety within one molecule. This means that one end of the molecule has a great affinity for water (hydrophilic), and another end repels the water (hydrophobic) [21] [22]. When spread over the water surface, molecules are released over the water surface to form a film of one molecule thickness [23]. These molecules stand on one end and provide an effective lid on the water surface [24] [25]. Figure 1 shows the amphiphilic molecules standing vertically on their polar head over the water surface.

Hexadecanol (Cetyl alcohol) $\mathrm{CH}_{3}\left(\mathrm{CH}_{2}\right)_{14} \mathrm{CH}_{2} \mathrm{OH}$ and octadecanol (Stearyl alcohol) $\mathrm{CH}_{3}\left(\mathrm{CH}_{2}\right)_{16} \mathrm{CH}_{2} \mathrm{OH}$ are suitable fatty alcohols to use for monolayers [22] [26]-[28]. These alcohols are derived from coconut or palm oil and are tasteless, odorless, non-toxic and inflammable. Cetyl and stearyl alcohol and their derivatives are biodegradable and innocuous to humans and animals. The United States Food and Drug Administration have approved them for use in the cosmetic, food and medicinal and industries indicating none to low toxicity [29]. When these materials are applied to the water surface, they self-spread to create a monomolecular surface film that provides an evaporative resistance [30]-[33]. A mixture of Cetyl alcohol and Stearyl alcohol in 1:1 ratio is found to be more effective than a monolayer consisting of any single material [18] [34] [35].

The mixture of Cetyl alcohol and Stearyl alcohol can be spread on the water surface in a powder form or an emulsion form, but the powder form has shown better results. This mixture forms a tight monomolecular layer on the water surface with the maximum surface pressure $40 \mathrm{mNm}^{-1}$. The layer allows oxygen and carbon dioxide to pass through but it is tight enough to prevent water molecules from escaping. The film formed does not resist sunlight and thus does not affect aquatic life [35]-[37].

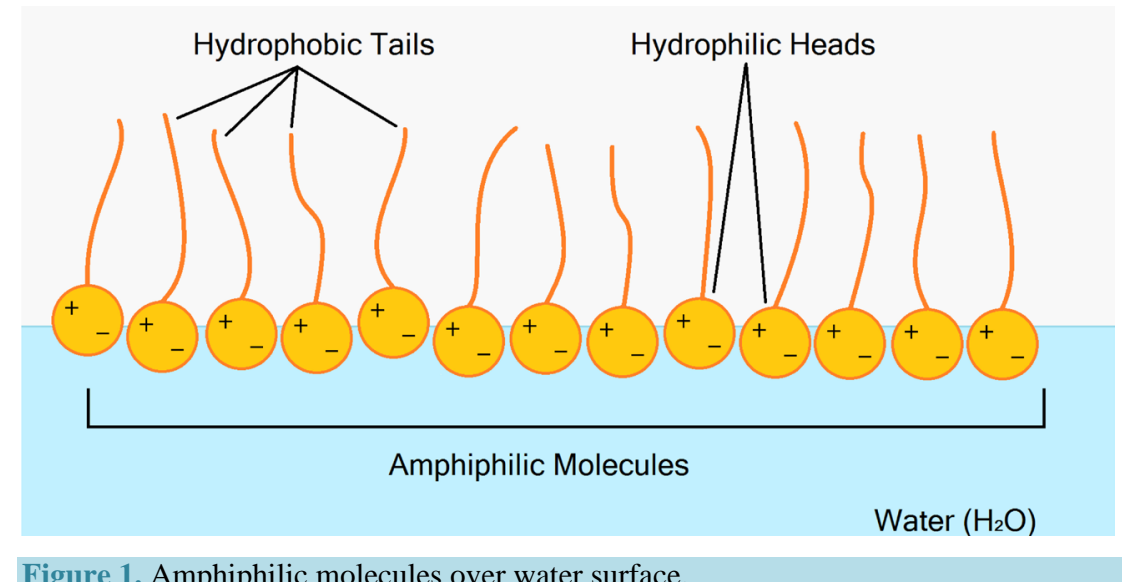

Figure 1. Amphiphilic molecules over water surface. 
When formed, this film has liquid-like properties, and if ruptured, the molecules flow towards the ruptured areas and repair the film. The film expands at the water surface as waves are formed while the surface pressure is decreased [38]. As the film is transparent and invisible, indicator oils are used on large water surfaces to detect a monolayer which involves placing some drops of the indicator oil on the surface. If the film is formed and has acquired sufficient surface pressure, the oil drop will stand erect on it else it will sink in the water [23]. Numerous field trials on monolayers to reduce water evaporation have been carried out over the past 60 years. Most trials have used either Cetyl or Stearyl alcohol predominately and have found water savings ranging from 8 percent up to 43 percent [32] [39].

The main purpose of the present investigation was to develop a practical, safe and effective method of treating the surface of reservoir water with a monomolecular chemical film to reduce evaporation loss. An experiment was carried out at the Aji reservoir by using a mix of Cetyl and Stearyl alcohol, which confirmed a saving of $19.26 \%$ in evaporation loss. During this six-month trial, 0.18 mcum of water was saved from being evaporated.

\section{Material and Method}

Many organic compounds composed of long chain molecules having unsaturated valences at one end are easily attracted by water molecules and hence, lead to their spreading over a clean water surface [32]. The molecules encored to the water surface constitute a mono-molecular film. The longer the chain of the molecules, the greater is the sidewise attraction between the above water portions of the molecules. This sidewise attraction needs to be able to overcome random movements of the water attached ends if a stable, coherent, compact and mono-molecular film is to provide an effective lid onto the water surface [31] [40].

An ideal material which can spread over water the surface and act as a sealant should possess the following properties:

- Tasteless, odorless, non-toxic and nonflammable.

- Form a compact mono-molecular film and develop a surface pressure of more than 20 dynes to prevent water molecules from escaping.

- Pervious to oxygen and carbon dioxide but tight enough to prevent the escape of water molecules. It should not resist the passage of sunlight: in other words, it should not affect the aquatic life.

- Economical and relatively stable.

Hexadeconal (Cetyl alcohol) and octadecanol (Stearyl alcohol) have been studied extensively to determine their effectiveness as a film forming agent to reduce evaporation from water surfaces [15] [22] [41]. This material is a white, waxy, crystalline solid and generally available in flakes or powder form. It is relatively tasteless and odorless. It is derived from Tallow, sperm oil, coconut oil or palm oil.

The monomolecular film formed by a mixture of Cetyl and Stearyl alcohols in 1:1 ratio provides a stronger and more stable film on water surfaces than single Water Evaporation Retardant (WER) material [34] [35]. This film offers a barrier to prevent water molecules from escaping from the water body due to evaporation; the film can be penetrated by raindrops which break the film, but it closes again. It is flexible and moves with the motion of the water surface. It does not easily break up as do thick films formed by heavy oils. The theoretical quantity of Cetyl/Stearyl alcohol required to cover 1 ha of the open water surface is $21 \mathrm{gm}$ under calm laboratory conditions.

\subsection{Methods of Spreading the Material}

There are three methods to spread the WER material over the open water surface.

1) The material Cetyl/Stearyl alcohol is available in flakes and lumps. This is pulverized in a cold grinding process as their melting point is about $49^{\circ} \mathrm{C}$. The pulverized material should be 60 to 100 mesh size for spreading over the water surface, and its dusting should be carried out by the help of a motor-driven boat and a powder duster. The material should be spread uniformly all over the water surface.

2) Cetyl/Stearyl alcohol is dissolved in kerosene or turpentine and applied over the water surface. The solution spreads rapidly and as the solvent evaporates this result in a one-molecule-thick lipid film at the air/water interface. Kerosene and Turpentine being less volatile may leave a lasting odor and hence they should not be preferred. Ether can be used because after application it evaporates quickly, leaving the monomolecular layer of Cetyl/Stearyl alcohol over the water surface [42]. In this case, the cost of the solvent adds to the cost of spreading.

3) The attempt to spread the material in the form of an emulsion over water surface is found favored in some 
countries, but the conclusion regarding this simpler and cheaper technique is yet to be determined. The emulsion may be spread over the water surface by boat or by stationary rafts carrying an emulsion container with an arrangement to feed drop by drop emulsion on the water surface.

The research conducted by Yan et al. (2009) [43] shows that the dry dusting method results in a better monomolecular film than spreading the material in soluble or emulsion form. Figure 2 displays the pictures of dry dusting over the water surface of the Aji reservoir using a motor driven boat and a stationery raft with the container carrying WER material in emulsion form with an arrangement to slowly release it over the water surface of the Nyari dam (India).

\subsection{Measurement of Surface Pressure}

There are many sophisticated techniques to measure the surface tension of monomolecular films such as photographic techniques, microwave techniques, thermal techniques etc. [44]. One simple technique that has been used on large water surfaces to identify a monolayer involves placing drops of indicator oil on the surface. As the naked eye can not see the film, its formation and surface pressure on the field can be measured by oil drops. If the film is formed and has acquired sufficient surface pressure, the oil dropped on the water surface will stand erect on it. But if the film is not there or it has not acquired sufficient surface pressure, the oil drops will sink in the water and immediately spread [23] [45].

For testing the film pressure, the following indicator oils are used:
1) Shell vitea 13
16 dynes.
2) Shell vitrea 21
3) Shell exists fluid 250
24 dynes.
40 dynes.

\subsection{Effect of Cetyl/Stearyl Alcohol Film on Reservoir Water}

Extensive studies in U.S.A., Australia, and other countries have been conducted on the biological effects of fatty alcohol and these studies have established that there are no adverse effects (short and long term) on the suitability of water for human consumption where reservoir surfaces are treated [29] [46]. Field and laboratory investigations have shown that both hexadecanol and octadecanol pose a very minimal toxicological threat to both aquatic and terrestrial life forms such as fish, ducks, insects, and plants [23] [41] [47]. As the film permits oxygen and sunlight to pass, it does not affect the aquatic life [36].

\subsection{Dependence of Evaporation Control on Temperature}

Laboratory Experiments at Poona (India) showed that the percent of evaporation control due to the monomolecular film of Cetyl/Stearyl alcohol decreases from 60 percent at a water surface temperature of $20^{\circ} \mathrm{C}$ to 13 percent at $60^{\circ} \mathrm{C}$ [48]. Table 1 shows the effect of temperature on the resistive capacity of the monomolecular film.
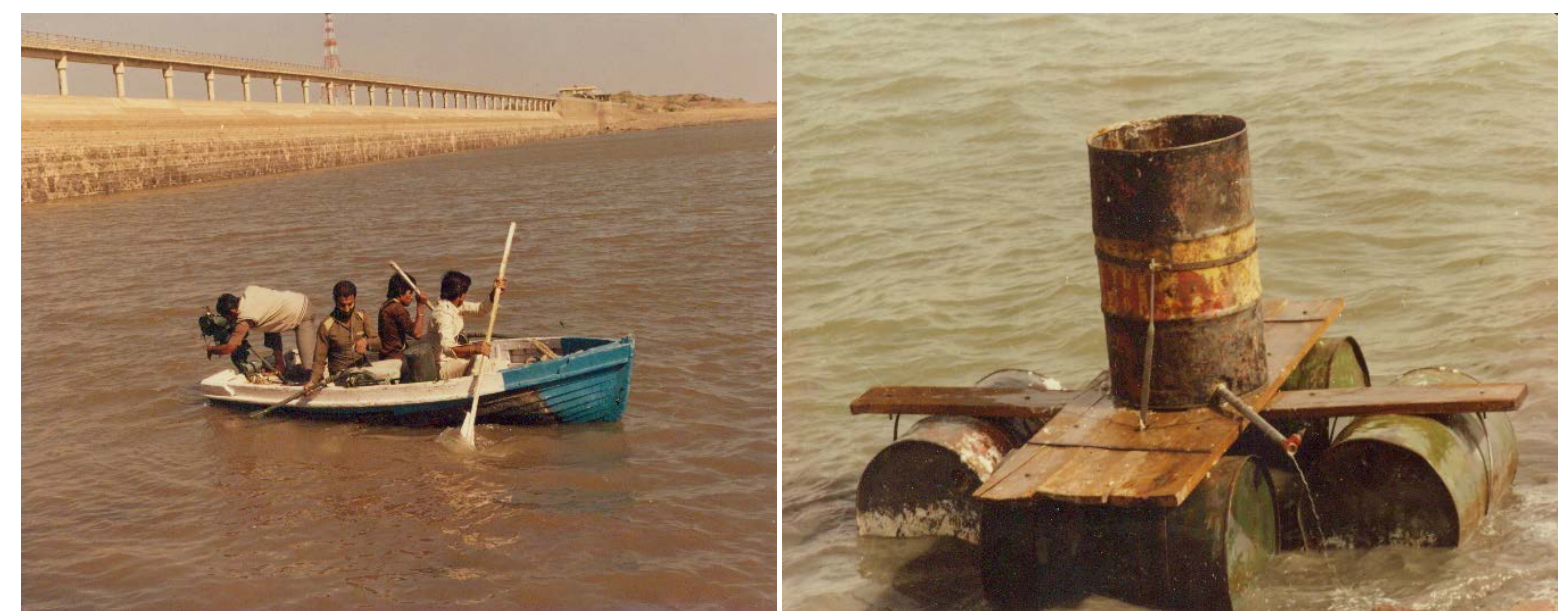

Figure 2. Pictures showing dry dusting over lake surfaces by motor driven boat and stationary raft carrying a container with an arrangement to feed emulsion drop. 
Table 1. Effect of temperature over evaporation resisting capacity of the film.

\begin{tabular}{cccc}
\hline Water surface temperature & \multicolumn{3}{c}{ Reduction in evaporation (\%) } \\
\cline { 2 - 4 }$\left({ }^{\circ} \mathrm{C}\right)$ & Cetyl alcohol & Stearyl alcohol & Cetyl-Stearyl alcohol \\
\hline 20 & 60.1 & 82.5 & 80.3 \\
30 & 35.8 & 70.5 & 64.7 \\
40 & 24.7 & 55.9 & 54.7 \\
50 & 18.6 & 42.9 & 40.7 \\
60 & 13.8 & 30.9 & 29.1 \\
\hline
\end{tabular}

\subsection{Dependence of Evaporation Control on the Wind}

Monomolecular films applied to lake surfaces for evaporation retardation are greatly affected by the local wind speed and direction [49]-[52]. In field studies at Lake Hefner in Oklahoma, the U. S. Bureau of Reclamation researchers found the wind to be the most important single factor in the application and maintenance of a film When the wind velocity increases beyond 12 to $15 \mathrm{~km}$. per hour, the scraping action of wind on the monomolecular film on the water surface sets in [39] [53] [54]. This decreases the film cover on the foreshore and heaps it up on the wind-wend side, even depositing a part of it on the offshore of the reservoir. Much larger rates of dispensing of the film, sufficient to obviate the effect of the wind will thus be needed to maintain the film cover as effectively as possible. Under these conditions the amount of Cetyl or Stearyl alcohol that goes as unavoidable waste increases several fold. The amount of the alcohol to be spread may have to be increased under little or no wind conditions. If more wind is observed on a particular day spreading should be cancelled to avoid waste [55].

\subsection{Life of Monomolecular Film over Water}

Experiments in the laboratory with distilled water have shown that the lifespan of such films is about three days. But under field conditions, it is reduced to one to two days. The destruction of material takes place by the effect of chemical bacteria's and wind action. [56] [57]. The solubility of heavy alcohols in the water is very low. There is a reason to believe that the ultraviolet sun rays break down the heavy alcohols into substances of shorter chain lengths, which are then lost. Experiments carried out in different parts of the world show that in the arid or semi-arid areas where human, animal and bird life are extremely scarce, as in the arid zone of Australia, bacterial action on the film is very rare. But in thickly populated areas in the tropics and subtropics the bacterial destruction plays a more prominent part [58].

Any foreign substance which is absorbed by the film restricts its movement by rendering it inelastic. In this state, the film instead of flowing easily tends to be crumpled by the wind and gets washed away from the surface. The crumpled film clogged with impurities is ineffective and does not spread again, and it may sink.

\subsection{Spreading Procedure}

When Cetyl/Stearyl alcohol is spread over the water surface, molecules of the alcohol are released and spread over the water surface to form a film of one molecule thickness [40]. The rate of spreading depends on the composition of alcohol, the temperature of the water surface and prevailing wind velocity. As the spreading proceeds, the surface pressure gradually increases until an equilibrium pressure of 40 dynes is reached and at this stage, the film is condensed and provides maximum resistance to the evaporation of the water. The equilibrium film has the properties of a liquid, and if ruptured, the molecules will flow towards the rupture and repair the film. The film expands with the water surface as waves are formed but the pressure is decreased.

During periods of normal temperature and low wind, the film of Cetyl/Stearyl alcohol develops a surface pressure up to 40 dynes. Subsequent feeding can be done only to replenish the damaged portion of the film. It is advisable to have the film spread on the water during cooler and calmer hours of the day; the film, by its own presence, will reduce the waves and lessen the destructive effects of the wind. From meteorological studies, it can be seen that wind and temperature increases during the afternoon hours. Thus, it is better if the film is formed in the early hours of the day. The surface pressure of the film should be tested at intervals, and additional quantities should be added to make up the deficit. Field studies suggest that a fresh film has to be formed every day [55]. 


\subsection{Assessment of the Evaporation from a Reservoir and the Saving Due to Film}

Water evaporation is one of the obscure components of the hydrological cycle to measure accurately. There are two basic reasons for this obscurity. First, no instrumentation exists which can truly measure evaporation from a natural surface. Second, none of the indirect methods used for estimating evaporation are universally accepted. Estimation of reliable or acceptable values of evaporation requires either a detailed instrumentation or a judicious application of climatic and physical data.

Thornthwaite and Benjamin (1942) [59] proposed a recondite technique of an aerodynamic method whereby the evaporative loss is correlated with the transfer of water vapour by turbulence into the air layers near the surface. This in turn, may be assessed from the vertical gradients of wind velocities and vapour pressure. But this technique needs specialized equipment and skills which are ordinarily beyond the reach of engineers working in the field.

\subsubsection{Pan Evaporimeter Method}

The simple two pan method can be used to assess the water saved from evaporation loss as a result of covering the water surface of one pan with a monomolecular layer. The difference in evaporation depths by two panevoporimeters kept side by side, with the water of one pan dusted with WER material will provide the depth of water saved. Kohler et al. (1955) [60] suggested that lake evaporation (E) is 0.70 times the standard pan evaporation (Es).

\subsubsection{Water Balance Method}

The basic water balance equation can be written as

$$
F=W+E+S
$$

where $F=$ Fall of level, $W=$ Water drawn for supply, $E=$ Reservoir evaporation and $S=$ Seepage and absorption losses.

The calculation of seepage loss ' $S$ ' is a very difficult task. Floating pans can be used for directly measuring $E$, but this is often beset with difficulties particularly during windy weather. It is more practical to determine the relation between $E \& E s$, where $E s$ is a standard land pan evaporimeter well away from the direct influence of the reservoir.

Another practicable approach is to have alternating periods of "No Treatment" and "Treatment", where the estimation of savings becomes a simple matter as one may assume that in adjoining weekly or 10 day intervals, the value of ' $S$ ' may not change materially, and one may reasonably compare the evaporation in a treated week with that in the previous untreated week. In actual practice, great care is necessary in arriving at representative values of water levels by using a number of gauges.

\section{Experiment on the Aji Reservoir}

The Aji reservoir is located at $22.3^{\circ} \mathrm{N} 70.78^{\circ} \mathrm{E}$ near Rajkot city in Gujarat state (India) and has an average elevation R.L 134 metre. It is the main source of the municipal water supply for the city of Rajkot. The main spillway portion of the Aji dam and its geographic location is shown in Figure 3.

Rainfall in the year 1985-86 in the western Gujarat region was very scanty, and only 195 mm of rain was recorded which was well below the annual average of $900 \mathrm{~mm}$. This too was spread over 33 rainfall days. The maximum rainfall in any day was reported to be a meager $18 \mathrm{~mm}$. As a result, the lakes and reservoirs of the area received very little, or no replenishment and a very grave situation arose in supplying water supply to Rajkot city with a population of about a million people. Therefore, it was decided to carry out an experiment in the Aji Reservoir to conserve available water storage.

\subsection{Weather Pattern of the Aji Reservoir}

The monthly average maximum temperature varies from $25^{\circ} \mathrm{C}$ to $42^{\circ} \mathrm{C}$ and the minimum temperature varies between $8^{\circ} \mathrm{C}$ to $27^{\circ} \mathrm{C}$. Usually, the daytime temperature rises from forenoon to the afternoon and then gradually falls. During the summer months where the maximum daytime temperature ranges from $40^{\circ} \mathrm{C}$ to $45^{\circ} \mathrm{C}$, evaporation losses from the reservoir are at their maximum. As far as wind and temperature conditions at Aji reservoir are concerned, during the summer months of high daytime temperatures, wind velocities are also higher. In the 


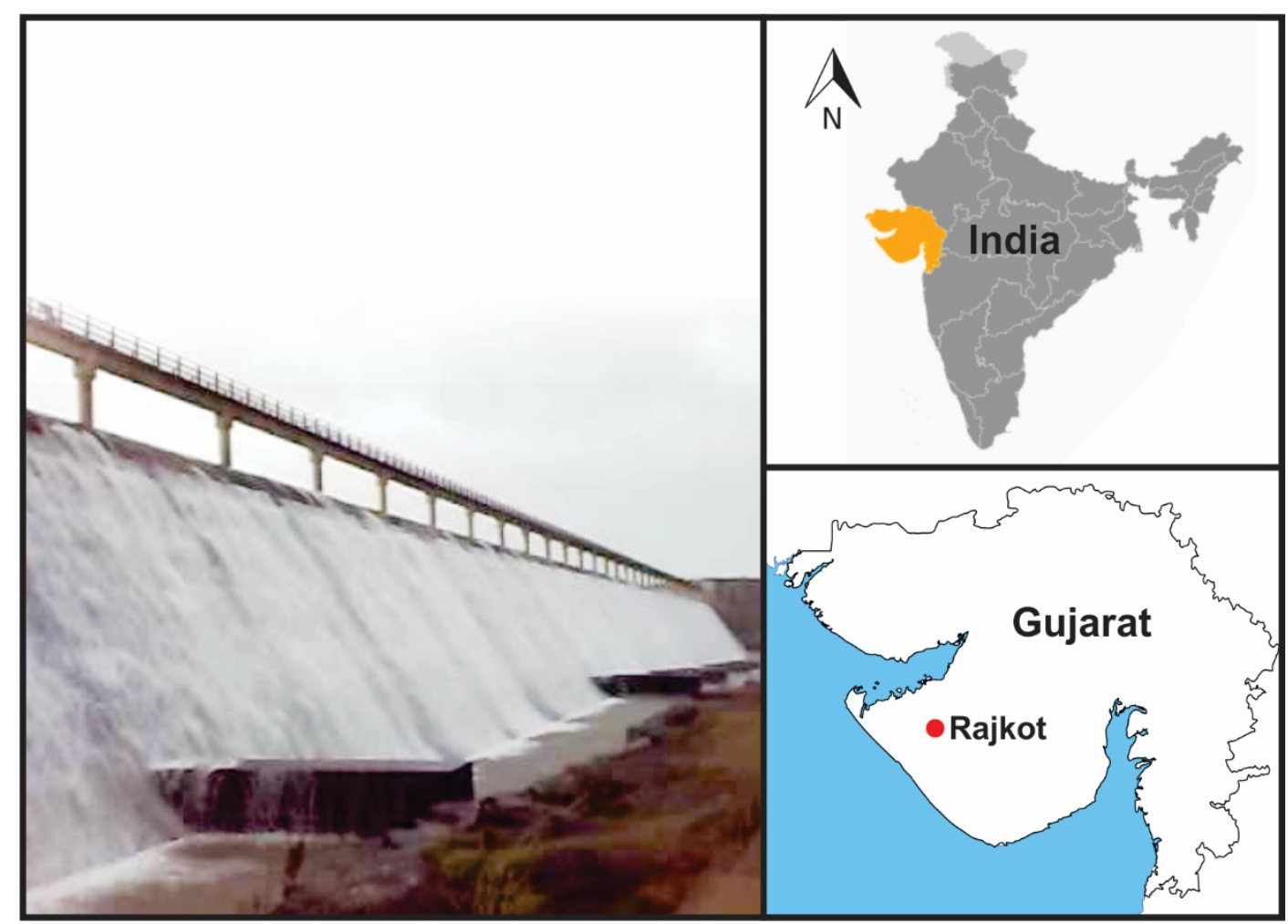

Figure 3. Aji dam near Rajkot city (India).

months of October and November although the daytime temperature is high, wind velocities are comparatively less. During the winter season, wind and temperature conditions are comparatively better.

It was observed that the wind velocities on the Aji reservoir were less in winter than in the summer season. The maximum wind velocity recorded during December was $9 \mathrm{~km} / \mathrm{hr}$ and linearly increased to $15 \mathrm{~km} / \mathrm{hr}$ in the month of June. Also, wind velocity during the day was at its maximum between 12.00 to 16.00 hrs.

\subsection{Dusting Operations}

The experiment was carried out from December 15, 1985, to May 31, 1986, and within this period; the mixture of Cetyl alcohol and Stearyl alcohol in 1:1 ratio was used. The chemical was pulverized daily up to 100 microns in a special mill in the laboratory of Pharmacy College located about $1 \mathrm{~km}$ from the Aji reservoir. It was observed that if the pulverized powder was stored for 2 to 3 days, it converted to lumps due to the high summer temperatures; hence, grinding was carried out daily.

The required quantity of powder was calculated daily according to the decreasing water spread area due to a decrease in the reservoir level. The dusting operation in the reservoir was carried out using a gasoline-driven motor boat. The dusting men sit in the rear of the boat and spray the powder by slowly rotating the handle of the dusting bin. The funnel of the bin was kept reasonably near the water surface. The dusting was carried out by running the boat in the opposite direction of the wind to ensure that the wind-blown particles of powder were able to fall on the water surface and not be wasted. The dusting operation was carried out in strips, and great care was taken to spray powder evenly on the entire surface of the water.

The dusting operations were carried out in the early hours of the morning from 4.00 AM to 7.00 AM as the weather conditions were calm during this period. The film formation was then checked at regular intervals by using castor oil drops at several points in the reservoir, and if needed, additional feeding was carried out during the day to replenish the damaged portion of the film.

Two Class A evaporation pans with a Stevenson screen were kept just in $\mathrm{d} / \mathrm{s}$ of the Aji reservoir. In one pan, the water surface was dusted with Cetyl/Stearyl alcohol powder and evaporation readings were taken from these two pans at regular intervals. 


\subsection{Seepage Loss and Saving in Evaporation Loss Calculation}

The six-month period from Jan 01, 1985 to June 30, 1985, was chosen to determine the seepage loss of the reservoir. The reservoir was not treated during this period.

Equation (1) can be rewritten as

$$
(F-W)=E+S
$$

If $\mathrm{P}$ is the evaporation loss from evaporation pan. Then

$$
m=E / P \text { or } E=m P
$$

From Equations (2) and (3)

$$
(F-W)=m P+S
$$

The graph is a straight line

$$
Y=m X+C
$$

The intercept on the $\mathrm{Y}$-axis in Figure 4 represents the seepage and absorption losses. These losses ' $\mathrm{S}$ ' are assumed to be constant for a given condition in the reservoir. Data for calculation of seepage and absorption loss of the Aji reservoir is shown in Table 2.

Figure 4 shows the graph of $\Sigma F-W$ versus cumulative evaporation $\Sigma m P$. In this straight line graph, the intercept $C$ of trend line denotes total seepage and absorption loss " $S$ " $=0.07 \mathrm{~m} / \mathrm{month}$. Table 3 and Table 4 show the data and effect of the use of WER material for the experimental period, of six-months.

The calculations show that an average of $19.26 \%$ savings of water was achieved during the experimental period and 0.18 mcum water was saved by the treatment.

\begin{tabular}{|c|c|c|c|c|c|c|c|}
\hline Period & $\begin{array}{c}\text { Drop in } \\
\text { water level }\end{array}$ & $\begin{array}{c}\text { Withdrawal for } \\
\text { water supply }\end{array}$ & $\begin{array}{l}\text { Total lake } \\
\text { loss }\end{array}$ & $\begin{array}{c}\text { Cumulative lake } \\
\text { loss }\end{array}$ & $\begin{array}{l}\text { Evaporation } \\
\text { from pan }\end{array}$ & $\begin{array}{c}\text { Evaporation from } \\
\text { lake }\end{array}$ & $\begin{array}{c}\text { Cumulative lake } \\
\text { evaporation }\end{array}$ \\
\hline & (F) & (W) & $(F-W)$ & $\Sigma(F-W)$ & (P) & $\mathrm{mP}=\mathrm{P} \times 0.70$ & $\Sigma(\mathrm{mP})$ \\
\hline & (m) & (m) & (m) & (m) & (m) & (m) & (m) \\
\hline Jan '85 & 0.80 & 0.60 & 0.20 & 0.20 & 0.15 & 0.11 & 0.11 \\
\hline Feb '85 & 0.90 & 0.68 & 0.22 & 0.42 & 0.19 & 0.13 & 0.24 \\
\hline March '85 & 1.00 & 0.72 & 0.28 & 0.70 & 0.27 & 0.19 & 0.43 \\
\hline April ‘85 & 1.11 & 0.82 & 0.29 & 0.99 & 0.30 & 0.21 & 0.64 \\
\hline May ‘85 & 1.27 & 0.93 & 0.34 & 1.33 & 0.35 & 0.25 & 0.88 \\
\hline June '85 & 1.29 & 0.97 & 0.32 & 1.65 & 0.33 & 0.23 & 1.11 \\
\hline
\end{tabular}

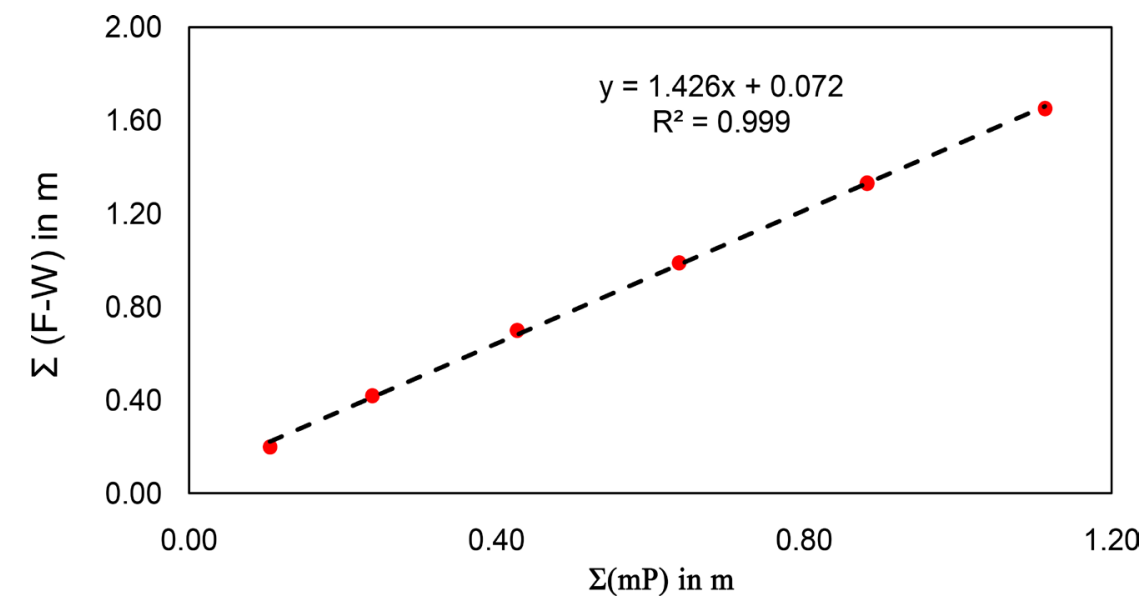

Figure 4. The straight line graph to calculate seepage and absorption losses of Aji reservoir.

Table 2. Statement for computation of seepage and absorption losses of the Aji reservoir. 
Table 3. Saving (\%) in evaporation by application of Cetyl/Stearyl alcohol treatment over the water surface.

\begin{tabular}{|c|c|c|c|c|c|c|c|c|c|c|}
\hline \multirow[t]{3}{*}{ Period } & $\begin{array}{c}\text { Drop in } \\
\text { water } \\
\text { level }\end{array}$ & $\begin{array}{l}\text { With-drawal } \\
\text { for water } \\
\text { supply }\end{array}$ & $\begin{array}{l}\text { Total } \\
\text { lake } \\
\text { loss }\end{array}$ & $\begin{array}{l}\text { Seepage } \\
\text { loss } 0.07 \\
\mathrm{~m} / \mathrm{month}\end{array}$ & $\begin{array}{l}\text { Evapo. } \\
\text { loss from } \\
\text { pan }\end{array}$ & $\begin{array}{l}\text { Lake } \\
\text { evapo. } \\
\text { loss }\end{array}$ & $\begin{array}{l}\text { Evapo. loss } \\
\text { without } \\
\text { treatment }\end{array}$ & $\begin{array}{l}\text { Evapo. loss } \\
\text { during treatment } \\
\text { period }\end{array}$ & $\begin{array}{r}\text { Sa } \\
\text { evapo } \\
\text { due to }\end{array}$ & $\begin{array}{l}\text { gin in } \\
\text { tion loss } \\
\text { eatment }\end{array}$ \\
\hline & (F) & (W) & $(F-W)$ & (S) & (P) & $\left(\mathrm{P}^{*} 0.70\right)$ & & (F-W-S) & & \\
\hline & $\mathrm{m}$ & $\mathrm{m}$ & $\mathrm{m}$ & $\mathrm{m}$ & $\mathrm{m}$ & $\mathrm{m}$ & $\mathrm{m}$ & $\mathrm{m}$ & $\mathrm{m}$ & $\%$ \\
\hline $\begin{array}{l}\text { 16-Dec-85 to } \\
\text { 31-Dec-85 }\end{array}$ & 0.30 & 0.23 & 0.07 & 0.03 & 0.07 & 0.05 & 0.05 & 0.04 & 0.01 & 18.37 \\
\hline Jan-86 & 0.53 & 0.37 & 0.16 & 0.07 & 0.16 & 0.11 & 0.11 & 0.09 & 0.02 & 19.64 \\
\hline Feb-86 & 0.39 & 0.21 & 0.18 & 0.07 & 0.20 & 0.14 & 0.14 & 0.11 & 0.03 & 21.43 \\
\hline Mar-86 & 0.43 & 0.18 & 0.25 & 0.07 & 0.31 & 0.22 & 0.22 & 0.18 & 0.04 & 17.05 \\
\hline Apr-86 & 0.43 & 0.17 & 0.26 & 0.07 & 0.34 & 0.24 & 0.24 & 0.19 & 0.05 & 20.17 \\
\hline \multirow[t]{2}{*}{ May-86 } & 0.45 & 0.17 & 0.28 & 0.07 & 0.37 & 0.26 & 0.26 & 0.21 & 0.05 & 18.92 \\
\hline & & & & & & \multicolumn{4}{|c|}{ Average saving in evaporation loss (\%) } & 19.26 \\
\hline
\end{tabular}

Table 4. Quantity of water saved by treatment.

\begin{tabular}{|c|c|c|c|c|c|c|c|}
\hline \multirow[t]{2}{*}{ Period } & \multirow{2}{*}{$\begin{array}{c}\text { Water level at the } \\
\text { beginning } \\
\text { (m) }\end{array}$} & \multirow{2}{*}{$\begin{array}{c}\text { Water level at } \\
\text { the end } \\
\text { (m) }\end{array}$} & \multirow{2}{*}{$\begin{array}{c}\text { Storage at the } \\
\text { beginning } \\
\text { (mcum) }\end{array}$} & \multirow{2}{*}{$\begin{array}{c}\text { Storage at the } \\
\text { end } \\
\text { (mcum) }\end{array}$} & \multirow{2}{*}{$\begin{array}{c}\text { Average water } \\
\text { spread area } \\
\text { (msqm) }\end{array}$} & \multicolumn{2}{|c|}{$\begin{array}{c}\text { Saving in evaporatior } \\
\text { due treatment }\end{array}$} \\
\hline & & & & & & $(\mathrm{m})$ & (mcum) \\
\hline $\begin{array}{l}\text { 16-Dec-85 to } \\
\text { 31-Dec-85 }\end{array}$ & 140.78 & 140.48 & 2.53 & 2.06 & 1.55 & 0.01 & 0.01 \\
\hline Jan-86 & 140.48 & 139.96 & 2.06 & 1.24 & 1.43 & 0.02 & 0.03 \\
\hline Feb-86 & 139.96 & 139.56 & 1.24 & 0.79 & 1.15 & 0.03 & 0.03 \\
\hline Mar-86 & 139.56 & 139.13 & 0.79 & 0.36 & 0.98 & 0.04 & 0.04 \\
\hline Apr-86 & 139.13 & 138.70 & 0.36 & 0.00 & 0.84 & 0.05 & 0.04 \\
\hline \multirow[t]{2}{*}{ May-86 } & 138.70 & 138.25 & 0.00 & -0.17 & 0.38 & 0.05 & 0.02 \\
\hline & & & & \multicolumn{3}{|c|}{ Total saving in evaporation } & 0.18 \\
\hline
\end{tabular}

\subsection{Economics of the Experiment}

Due to very scanty rainfall in the region around Rajkot city during 1985 monsoon, water supply lakes, and reservoirs received very poor replenishment. A very grave situation arose in the municipal water supply to one million residents of Rajkot with the summer months still ahead. The situation was so critical that authorities had to arrange for water by any means of transportation or to evacuate the city. To cope with this situation water was transported from distant places by road and by special trains. The cost for the transportation of 10,000 of litres water came to $\$ 7.0$ by road and $\$ 3.0$ by rail while the cost of water savings by this experiment was $\$ 0.45$. Thus, the cost of saving water from this experiment was insignificant compared to the cost of other arrangements to bring water from distant sources.

Apart from the economics of the cost, there is a deeper human value which cannot be measured in terms or money. For instance in the case of Rajkot City, there were anxious moments when considering the question of evacuating the city due to a very acute shortage of water. The experiment on the Aji reservoir saved about 0.18 mcm of water which lasted for a further 15 days. Thus, the experiment was partially instrumental in saving Rajkot from the grueling experience of evacuation.

\section{Conclusions and Recommendations}

On the basis of this water saving experiment, the following conclusions were drawn:

- Though evaporation cannot be controlled fully in field conditions, partial control can be achieved with satisfactory results.

- The efficiency of evaporation retardation in terms of percent of water saved from evaporation losses decreases with increases in temperature and wind velocities at the reservoir site. 
- The cost of chemical must be taken into account in the routine treatment, but in the case of extreme circumstances it should not govern the consideration for saving water.

These conclusions point to the fact that efficiency of the control operation varies from site to site. In extreme circumstances, there cannot be any norm of the economy, but for the general year to year treatments, the merit of the site conditions of the lake governs. A lake encircled by high hill ranges in the wind direction is recommended as it will calm the conditions even if wind velocities are higher in the region. It can be achieved by planting huge trees all around the periphery of the reservoir. This green belt of trees will also help to reduce evaporation by increasing the moisture content of the air by the process of transpiration. The root system of these trees will resist erosion and help to reduce the rate of silting of the reservoir.

Monomolecular films of Cetyl/Stearyl alcohol offer the prospect of an economical solution to the evaporative loss of water from large storage sites. There is scope for further research for more improved formulations with increased resistance to high temperatures and wind stress.

\section{References}

[1] Crow, F.R. and Sattler, H. (1958) The Influence of Wind on Chemical Films for Reservoir Evaporation Retardation. Paper Presented at the Meeting of the Southwest-Southeast Sections of the American Society of Agricultural Engineers at Little Rock, Arkansas.

[2] Freeze, S.W. (1956) Reservoir Evaporation Control by Other Means. Proceedings of the 1st International Conference on Reservoir Evaporation Control, San Antonio, 45-53.

[3] Sovocool, K., Morgan, M., Drinkwine, M., Sims, D. and Toussaint, G. (2014) Testing an Innovative Evaporative Suppressant for Reducing Losses from Lakes. Journal-American Water Works Association, 106, 41-50. http://dx.doi.org/10.5942/jawwa.2014.106.0054

[4] Ikweiri, F.S., Gabril, H., Jahawi, M. and Almatrdi, Y. (2008) Evaluating the Evaporation Water Loss from the Omar Muktar Open Water Reservoir. 12th International Water Technology Conference, IWTC, Alexandria, 893-899.

[5] Magin, G.B. and Randall, L.E. (1960) Review of Literature on Evaporation Suppression. Geological Survey Professional Paper 272-C. United States Government Printing Office, Washington DC, 53-69.

[6] Sinha, S.K., Kumar, L., Srivatsava, R., Thagamani, R., Kumar, S., Jha, S., Luthra, P.K. and Asutosh, P.A. (2006) Evaporation Control in Reservoirs. Central Water Commission, Basin Planning and Management Organisation, Government of India, Bhubneshwar.

[7] Xu, C.Y. and Singh, V.P. (1998) Dependence of Evaporation on Meteorological Variables at Different Time-Scales and Inter Comparison of Estimation Methods. Hydrological Processes, 12, 429-442. http://dx.doi.org/10.1002/(SICI)1099-1085(19980315)12:3<429::AID-HYP581>3.0.CO;2-A

[8] Reddy, P. (2004) A Text Book of Hydrology. Laxmi Publications, New Delhi.

[9] Varma, C.V.J. (1996) Evaporation and Its Restriction from Free Water Surfaces. A. A. Balkema Publishers, Rotterdam.

[10] Craig, I., Aravinthan, V., Baillie, C., Beswick, A., Barnes, G., Bradbury, R., Connell, L., Coop, P., Fellows, C., Fitzmaurice, L., Foley, J., Hancock, N., Lamb, D., Morrison, P., Misra, R., Mossad, R., Pittaway, P., Prime, E., Rees, S., Schmidt, E., Solomon, D., Symes, T. and Turnbull, D. (2007) Evaporation, Seepage and Water Quality Management in Storage Dams: A Review of Research Methods. Environmental Health, 7, 84-97.

[11] Jones, J.A.A. (2014) Water Sustainability: A Global Perspective. Routledge. Taylor and Francis Group, London and New York.

[12] Martínez-Granados, D., Maestre-Valero, J.F., Calatrava, J. and Martínez-Alvarez, V. (2011) The Economic Impact of Water Evaporation Losses from Water Reservoirs in the Segura Basin, SE Spain. Water Resources Management, 25, 3153-3175. http://dx.doi.org/10.1007/s11269-011-9850-x

[13] Schmidt, E. (2007) Controlling Evaporation Loss from Water Storages Using NetPro Shade Cloth. National Centre for Engineering in Agriculture University of Southern Queensland Toowoomba NCEA Publication No. 1000580/3.

[14] Barnes, G.T. (1993) Optimum Conditions for Evaporation Control by Monolayers. Journal of Hydrology, 145, 165173. http://dx.doi.org/10.1016/0022-1694(93)90225-X

[15] Dressler, R.G. and Guinat, E. (1973) Evaporation Control on Water Reservoirs. Industrial and Engineering Chemistry Product Research and Development, 12, 80-82. http://dx.doi.org/10.1021/i360045a013

[16] Machida, S., Mineta, S., Fujimori, A. and Nakahara, H. (2003) Retardation of Water Evaporation by Less-Defective Mixed Monolayers Spread from Bulk Solids onto Water Surface. Journal of Colloidal and Interface Science, 260, 135141. http://dx.doi.org/10.1016/S0021-9797(02)00222-9

[17] Yao, X., Zhang, H., Lemckert, C., Brook, A. and Schouten, P. (2010) Evaporation Reduction by Suspended and Float- 
ing Covers: Overview, Modelling and Efficiency. Urban Water Security Research Alliance Technical Report No. 28.

[18] Gugliotti, M., Baptista, M.S. and Politi, M.J. (2005) Reduction of Evaporation of Natural Water Samples by Monomolecular Films. Journal of the Brazilian Chemical Society, 16, 1186-1190.

[19] Hightower, M. and Brown, G. (2004) Evaporation Suppression Research and Applications for Water Management. Identifying Technologies to Improve Regional Water Stewardship: North-Middle Rio Grande Corridor, 76-83.

[20] Rideal, E.K. (1925) Influence of Thin Surface Films on the Evaporation of Water. The Journal of Physical Chemistry, 29, 1585-1588. http://dx.doi.org/10.1021/j150258a011

[21] Rosano, H.L. and La Mer, V.K. (1956) The Rate of Evaporation of Water through Monolayers of Esters, Acids and Alcohols. Journal of Physical Chemistry, 60, 348-353. http://dx.doi.org/10.1021/j150537a024

[22] Reiser, C.O. (1969) System for Controlling Water Evaporation. Industrial and Engineering Chemistry Process Design and Development, 8, 63-69. http://dx.doi.org/10.1021/i260029a011

[23] Timblin, L.O., Moran, W.T. and Garstka, W.U. (1957) Use of Unimolecular Layers for Reservoir Evaporation Reduction. American Water Works Association Journal, 49, 841-848.

[24] Katti, S.S., Kulkarni, S.B., Gharpurey, M.K. and Biswas, A.B. (1962) Control of Water Evaporation by Monomolecular Films. Journal of Scientific and Industrial Research, 21, 434-437.

[25] Tran, D.N.H., Prime, E.L., Plazzer, M., Leung, A.H.M., Yiapanis, G., Christofferson, A.J., Yarovsky, Y., Qiao, G.G. and Solomon, D.H. (2013) Molecular Interactions behind the Synergistic Effect in Mixed Monolayers of 1-Octadecanol and Ethylene Glycol Monooctadecyl Ether. The Journal of Physical Chemistry B, 117, 3603-3612. http://dx.doi.org/10.1021/jp401027c

[26] Christopher, M.F. Paul, A.C., David, W.L., Ronald, C.B., Helmut, F.S. and Andrew, J.W. (2015) Understanding the Role of Monolayers in Retarding Evaporation from Water Storage Bodies. Chemical Physics Letters, 623, 37-41. http://dx.doi.org/10.1016/j.cplett.2015.01.027

[27] Langmuir, I. and Langmuir, D.B. (1927) The Effect of Monomolecular Films on the Evaporation of Ether Solutions. The Journal of Physical Chemistry, 31, 1719-1731. http://dx.doi.org/10.1021/j150281a011

[28] O’Brien, R. (2001) Film-Spreading Powder for Suppressing Water Evaporation. US Patent 6,303,133.

[29] Fisk, P.R., Wildey, R.J., Girling, A.E., Sanderson, H., Belanger, S.E., Veenstra, G., Nielsen, A., Kasai, Y., Willing, A., Dyer, S.D. and Stanton, K. (2009) Environmental Properties of Long Chain Alcohols. Part 1: Physicochemical, Environmental Fate and Acute Aquatic Toxicity Properties. Ecotoxicology and Environmental Safety, 72, 980-995. http://dx.doi.org/10.1016/j.ecoenv.2008.09.025

[30] Bower, S.M. and Saylor, J.R. (2013) Sherwood-Rayleigh Parameterization for Evaporation in the Presence of Surfactant Monolayers. AIChE Journal, 59, 303-315. http://dx.doi.org/10.1002/aic.13792

[31] La Mer, V.K. and Healy, T.W. (1965) Evaporation of Water: Its Retardation by Monolayers. Science, 148, 36-42. http://dx.doi.org/10.1126/science.148.3666.36

[32] Prime, E.L., Leung, A., Tran, D., Gill, H., Solomon, D., Qiao, G. and Dagley, I. (2012) New Technology to Reduce Water Evaporation from Large Water Storages. National Water Commission Canberra ACT 2600.

[33] Martínez-Alvarez, V., Gallego-Elvira, B., Martín-Gorriz, B., Pittaway, P. and Brink, G. (2012) Experimental Assessment of artificial Monolayers in Reducing Evaporation from Water Storages. International Conference of Agricultural Engineering, Valencia.

[34] McArthur, I.K.H. and Durham, K. (1957) Fatty Alcohols for Water Conservation. International Congress on Surface Activity, 2nd, Proc., London, Preprint 1, AL, 208-215.

[35] Yan, W., Bingwen, W., Qingzhu, J. and Wei, Z. (2009) Study on Retardation of Water Evaporation by Single and Mixed Monolayers at Air/Water Interface. International Conference on Environmental Science and Information Application Technology, 1, 179-182.

[36] Craig, I., Green, A., Scobie, M. and Schmidt, E. (2005) Controlling Evaporation Loss from Water Storages. National Centre for Engineering in Agriculture Publication 1000580/1, USQ, Toowoomba.

[37] Timblin, L.O., Florey, Q.L. and Garstka, W.U. (1962) Laboratory and Field Reservoir Evaporation Reduction Investigations Being Performed by the Bureau of Reclamation. In: La Mer, V.K., Ed., Retardation of Evaporation by Monolayers: Transport Processes, Academic Press, New York, 177-192.

[38] Frenkiel, J. (1965) Evaporation Reduction. Physical and Chemical Principles and Review Experiments. UNESCO.

[39] McJannet, D.L., Cook, F., Knight, J. and Burn, S. (2008) Evaporation Reduction by Monolayers: Overview, Modelling and Effectiveness. Urban Water Security Research Alliance Technical Report No. 6.

[40] Barnes, G.T. (2008) The Potential for Monolayers to Reduce the Evaporation of Water from Large Water Storages. Agricultural Water Management, 95, 339-353. http://dx.doi.org/10.1016/j.agwat.2007.12.003 
[41] Berger, B.B. (1958) Use of Hexadecanol in Reservoir Evaporation Reduction. American Water Works Association Journal, 50, 855-858.

[42] Brown, R.E and Brockman, H.L (2013) Using Monomolecular Films to Characterize Lipid Lateral Interactions. Methods in Molecular Biology, 398, 41-58. http://dx.doi.org/10.1007/978-1-59745-513-8 5

[43] Yan, W., Bingwen, W., Qingzhu, J. and Wei, Z. (2009) Study on Water Evaporation Retardants with Abilities of Anti-Environmental Interference. International Conference on Environmental Science and Information Application Technology, 1, 183-185. http://dx.doi.org/10.1109/esiat.2009.425

[44] Barnes, G.T. and Gentle, I.R. (2005) Interfacial Science: An Introduction. Oxford University Press, Oxford.

[45] Grundy, F. (1962) Some Problems of Maintaining a Monomolecular Film on Reservoirs Affected by Winds. In: La Mer, V.K., Ed., Retardation of Evaporation by Monolayers: Transport Processes, Academic Press, New York, 213218. http://dx.doi.org/10.1016/b978-1-4832-2947-8.50020-3

[46] Cruse, R.R. and Harbeck, G.E. (1960) Evaporation Control Research, 1955-58. Geological Survey Water-Supply Paper 1480.

[47] Hayes, M.L. (1959) Biological Effects of Hexadecanol Used to Suppress Water Evaporation from Reservoirs. Fort Collins Colorado, Colorado State University.

[48] Kulkarni, S.Y. and Kapre, A.C. (1987) Conservation of Water by Use of Chemical. First National Convention, New Delhi.

[49] Price, W.H., Garstka, W.V. and Timblin, L.O. (1959) Treatment and Film Evaluation; Results of the Engineering Studies. Water-Loss Investigations: Lake Hefner 19-8 Evaporation Reduction Investigations. Report by the Collaborators.

[50] Crow, F.R. and Daniel, E.R. (1958) Chemicals for Controlling Evaporation from Open Water Surfaces. Transactions of the American Society of Agricultural Engineers, 1, 72-75. http://dx.doi.org/10.13031/2013.41219

[51] Crow, F.R. (1961) Reducing Reservoir Evaporation; Application of Surface Films Cuts Losses. Agriculture Engineering, 42, 240-243.

[52] Hancock, N.H., Pittaway, P.A. and Symes, T.W. (2011) Assessment of the Performance of Evaporation Suppressant Films: Analysis and Limitations of Simple Trialing Methods. Australian Journal of Multi-Disciplinary Engineering, 8, 2, 157-167.

[53] Fitzgerald, L.M. and Vines, R.G. (1963) Retardation of Evaporation by Monolayers: Practical Aspects of the Treatment of Large Water Storages. Australian Journal of Basic and Applied Sciences, 14, 340-346.

[54] Condie, S.A. and Webster, I.T. (1995) Evaporation Mitigation from On-Farm Water Storages. CSIRO, Canberra.

[55] Panjabi, K. (1989) Water Evaporation Retardation by Monomolecular Layers: A Case Study of Aji Reservoir. Project report submitted to Department of Hydrology, University of Roorkee, India.

[56] Boon, A.G. and Downing, A.L. (1957) Observations on the Use of Cetyl Alcohol for Conservation of Water. Institute of Water Engineers Journal, 11, 443-448.

[57] Chang, S., McClanahan, M. and Kabler, P. (1962) Effect of Bacterial Decomposition of Hexadecanol and Octadecanol in Monolayer Films on the Suppression of Evaporation Loss of Water. In: La Mer, V.K., Ed., Retardation of Evaporation by Monolayers. Transport Processes, Academic Press, New York, 119-131. http://dx.doi.org/10.1016/b978-1-4832-2947-8.50013-6

[58] Larson, R.J. and Games, L.M. (1981) Biodegradation of Linear Alcohol Ethoxylates in Natural Waters. Environmental Science and Technology, 15, 1488-1493. http://dx.doi.org/10.1021/es00094a011

[59] Thornthwaite, C.W. and Benjamin, H. (1942) Measurement of Evaporation from Land and Water Surfaces. Technical Bulletin No. 817.

[60] Kohler, M.A., Nordenson, T.J. and Fox, W.E. (1955) Evaporation from Pans and Lakes. U.S. Department of Commerce, Weather Bureau, Research Paper No. 38, 21. 